Olha Tsikhotska,

PhD (Candidate of Pedagogical Sciences), associate professor,

Liudmyla Lozynska,

PhD (Candidate of Pedagogical Sciences), associate professor, Foreign Languages Department,

Vinnytsya National Pirogov Memorial Medical University, 56, Pyrohova Str., Vinnytsia, Ukraine

\title{
HUMANISM AND HUMANITY AS A FUTURE DOCTOR'S PERSONAL QUALITIES: CURRENT STATE AND WAYS OF FORMATION
}

The article is devoted to the problem of investigation of the formation of future doctors' value orientation in the process of studying foreign languages. The authors made an attempt to analyse the current level of humanistic value orientations' development in future doctors. The specific character of humanism-oriented education by means of the university subject "English Language" is discovered. The pedagogical conditions of the students' familiarisation with humanistic value orientations, which assist purposeful and effective management of this process, are revealed. The educational capacity of English-language study material is grounded and experimentally proved.

Keywords: value orientation, humanisation, English language, humanistic values, education, educational capacity of study material.

The Ukrainian law "On Education" (2016) underlines that education is "a combination of systemic knowledge and practical skills, ways of thinking, professional, social and ideological qualities, moral-ethic values and other competences received at a higher educational institution" [10]. In this hierarchy, moral-ethic values and their fostering should occupy the first place. This is due to the long time prerogative of professional qualities education in post-soviet educational practice.

The modern state of society in Ukraine is characterized by the deep crisis in the sphere of interpersonal relationships. The existing crisis differs much from the one in the $20^{\text {th }}$ century. At that time, the changes in the value system were forced by the changes within Ukrainian social being - exactly in political regime and economic system [7]. The modern axiological Ukrainian space is transforming under the influence of western values. Besides, living at war has an impact on every particular person, family, the society in general. In this situation, a teacher or educator cannot stay aside. He/she should not only provide the students with necessary information, but also influence their personality. The task of an educator is to help them become kind, humanistic and decent, be ready for cooperation and sympathy. It is vitally important to communicate to young people the laws of their existence, the main tendencies of life processes, teach them correct thinking, making right decisions, and seeing life perspectives.

In this context, it is important to optimise the processes of self-development, self-study, self-realisation and self-education. It comprises the ability for self- thinking / working / analysing and should be formed starting from the early childhood. The major part of modern Ukrainian youth, however, does not possess these qualities and one of the grounding reasons is the density of informational sphere that substantially differs in qualitative and quanti- tative aspect from the previous one. That is why the role of an educator as a guide through this information should not be underestimated.

Training and education are the two integral parts of the educational process. The essence of education is defined by the needs of socio-economic development of a particular social society. Education is social-historical and subjective self-realisation at a time, self-determination of an individual and individualism. It becomes the main component of any pedagogical process directed at the forming of personal qualities of a citizen on the bases of intellectual, moral, professional, physical development and national self-consciousness. It is important that the person receives and accepts the appropriate value orientations that will guide all his/her life. On the value orientation scale, humanism and humanity should occupy the leading positions.

The purpose of the article is to reveal the essence of the concept of doctor's humanism and to show experimentally proven ways of future physicians' value orientations formation in the educational process.

Humanism as a value system. The issue of humanism is reflected in philosophic, psychological, sociological and pedagogical aspects. The pedagogical one determines the ways of all-round and harmonic education of children and young people, clarifies the content of education in the modern society. Through the long history of humanity, the interest in the issue of humanism has always been high.

Humanism has accumulated all the basic norms and principles of moral communication between people, and has been one of the most flexible and reliable value systems produced by humanity over the past three centuries. Humanistic ideas were developed in ancient Chinese (Confucius) and Greek (Protagores, Platon, Socrates, Aristotle, Epicurus). The powerful start of humanistic 
ideas development was made in Renaissance period (Dante, Petrarchan), when respect for human rights was the main guide. Gradually the respect for human rights started to determine the axiological orientation of humanistic pedagogical tradition.

According to some of the researchers, the beginning of early humanistic culture formation in Ukraine is dated by the second part of $15^{\text {th }}-$ beginning of $16^{\text {th }}$ century. The development of spiritual culture is characterised by the formation of renaissance-humanistic and reformation ideas (I. Vyshensky, Yu. Drohobych, S. Orichovsky and others), which gradually formulated the certain orientations appearing on the bases of spiritual achievements of princely period.

The activity of fraternal schools, Kyiv-Mohyla Academy and Ostrozhsky Cultural-Educational Centre also contributed to the humanistic ideas' spreading. The famous representative of this period is the famous Ukrainian philosopher and traveller H. Skovoroda.

The period of Enlightenment witnessed such great humanists as Voltaire, Helvetious, Rousseau and others. The famous native humanists were H. Vashchenko, M. Pirohov, S. Russova, K. Ushynskyi, A. Makarenko,V. Sukhomlynskyi.

Humanism as a future doctor's value orientation. Humanism as a philosophy became also an integral part of education reflecting the principles of respect fora person, making a personality the centre of the pedagogical process.

Nowadays, when the modern Ukrainian educational system is being reformed, the special attention should be paid to the humanistic pragmatism, preserving the best humanistic features in the young generation, instilling respect for the personality, human rights, right for selfrealisation.

Choosing the system of values becomes the starting point in determining the content of education. In this content, the values are divided into transcendent (soul, immortality, hope, faith, love, repentance, and the like), socio-centric (freedom, equality, creativity, humanity, solidarity, consensus, and others) and anthropocentric (self-realisation, autonomy, interest, sincerity, and the like).

The value orientation system of the modern Ukrainian youth is often based on pragmatic aspirations. Their values and value orientations reflect the changes taking place in the society as a whole. The educational practice proves the fact that the humanistic values do not dominate in the value orientation system of the modern young students. We often face indifference, cruelty, absence of tolerance and mercy; students are often characterised by individualism and egocentrism, and even aggression [9].

Besides, the analysis of psychological and pedagogical literature proves that there is no unity as to the defining the concepts "humanism", "value", "value orientations". To evaluate the level of these concepts' understanding, the survey was conducted among the medical students of the first and second courses of study.
A doctor belongs to the most humanistic professions in the world. The youth period is characterised by the widening and restructuring of communication sphere. The subject of communication and the values discussed are determined by personal problems of the young people, their search for personal place in the society and intercommunication with it. At the beginning of their education, the future doctors constantly find themselves in the situations that require making a choice, finding solutions from the wide range of possibilities. This requires evaluation of possible alternatives, mostly in determining life perspectives. Being responsible for people's lives, making vital decisions, the doctor has to remain kind, honest, decent and sympathetic. All of the aforesaid implies that the educative process of higher educational institutions should be focused on preserving and multiplying future doctors' humanistic values.

Recently, the attempts were made to analyse the level of future doctor's humanity, but mostly they were concentrated on students of the senior courses and particularly their attitude to the patients $[1 ; 3 ; 4 ; 5 ; 6]$. The educators need more precise and profound knowledge about what is going on in the value orientation consciousness of their students, what is their life motto, what priorities do they have. Only this particular knowledge will provide the possibility for pedagogical correction.

The research included the formative and summative assessment of the formation of humanistic value orientations. 370 students of the first and second years of study took part in the assessment. When analysing the summative assessment, it has been found that only about $72 \%$ of future doctors can partially characterise "a humanist". They do not understand the social meaning of humanity, ability to compare themselves with others, love for other people, desire to protect dignity, resist cruelty and violence. The respondents could not give the characteristics to such qualities as tolerance and generosity. Only $7 \%$ of the first and second year students associate tolerance and generosity with condescension and common sense, the ability to forgive a person who made a mistake, did something wrong. No more than $11,5 \%$ of the students mention the main features and influence spheres of tolerance as attitude to interests, beliefs, convictions, behaviour and habits of other people; the desire to reach mutual understanding and consent of different interests and points of view without enforcement, mostly using explanation and conviction. Very few students admit that tolerance is a form of respect for the other person, acceptance of his/her right to personal beliefs (tolerance to representatives of the other political orientations, religious groups, moral habits and the like).

Almost $35 \%$ of the surveyed associate tolerance with patience, sufferance, the ability to tolerate pain, the necessity to experience something unpleasant or difficult. These students think that they should not protest even when they are offended. About $21 \%$ understand tolerance as modesty, ability to manage one's own emotions, not to show ill temper. 
The received results show that there is no clear understanding of the notions "humanity" and "humanism". A modern student is ready to retell everything he/she was taught, but is helpless when there is a need to use the knowledge in a certain situation, which proves the absence of the understanding of this knowledge. He/she lacks critical thinking and humanity.

According to the results, $50 \%$ of the respondents had the medium level of humanistic value orientations' development, $27.5 \%$ - the high one and $22.5 \%$ - the low level.

At the same time, the teachers at different educational institutions were questioned as for the ways and methods of education goals' implementation. $12 \%$ of them suppose that the education process at the English lessons is determined by the governmental politics, which influences the content of education. $56 \%$ are sure that the process, but not the result of studying the English language, should influence the students' general education. These answers reflect the tradition of ascribing the aims of education to the training aims and goals. With such an approach, they mostly remain only intentions.

The second stage of the summative assessment aimed to find out the attitude of the teachers to the formation of humanistic values in their students. It was found out that the teachers ( 37 respondents) mostly concentrated on instilling collectivism (53\%), industry (16\%), courtesy and kindness (12\%). As for collectivism, it should be also noted that this quality is often falsely understood and cultivated as identity of a person with the others, which interferes the process of personality formation.

In such a situation, one of the most important conditions ensuring the students' humanistic orientations is the humanisation of the study process through the selection of study material and methods of teaching. The educational technologies, which have been widely used lately, can help to solve these problems. We call them "innovations", which are based mostly on inter-subject connections of so-called "boundary" topics [2].

At the same time, the necessity of creating new individual education systems and programmes, choice situations, forming tolerance and respect for a person, acceptance of one's uniqueness is observed. The oldfashioned system of educational work is slowly vanishing. In today's educational technologies, the priority is given to "subject-subject" intercommunication models, which means the joint participation of adults and youth in mutual work.

The subjects of the so-called "humanitarian cycle" in the modern educational universities' curricular give educators the opportunity to influence the humanistic value orientations of a modern student. The subject "English Language" occupies the leading position among them.

Language being "the soul of nation" is characterised by several aspects: linguistic (the language description in a graphic or sound form), psychological (involves activity, individuality) and social, which is realised in the context of a person's social relationships. The university subject "English Language", like any other, has to perform its main functions - instructional, developmental and educational. It helps to form the understanding of the entire world, humanistic thinking and respect for values common to all mankind.

The methods of teaching English require defining aims and goals at each lesson, including the educational one. However, the teachers' orientation at pure study makes it impossible to use the educational potential of the subject. Most teachers suppose that embodiment of general instructional and educational goals at their lessons is only possible after the formation of the students' strong communication skills [10].

Technology of educating humanism. Using the experience of the Ukrainian and foreign colleges and taking into account the results of the survey, the experimental technology for educating humanism was created and experimentally tested. It has been proven that in the process of studying the English language at a medical higher educational institution, humanistic thinking and respect for general humanistic values can be formed and influenced. The humanisation of the study process is the key stone of this technology. It has the following components:

1. Defining emotional status in the group. Diagnosing the peculiarities of the students' emotional status requires observation and deep knowledge of psychology. As it is known, there are four types of temperament, which influence the dynamics of psychological activity. Temperament should be taken into consideration while developing the individual tasks for students.

The students' interests and tastes can be easily determined while studying such topics as "About myself", "My Working Day", "My Future Profession". The questioning of shy students should be done not at the blackboard, but at the place. The words "very well", "that's right" should be used more often for creating of cheerful atmosphere and involving students into communication, raising desire for mutual cooperation. The educators should favour positive moments, suggest the tasks that students are capable to fulfil, pay the group's attention to the successful results and general progress. In other words, study process humanisation involves not only individual approach to the students, but also the creating of a special psychological atmosphere.

2. Reducing students' anxiety. This requires giving up imperatives in speech and actions. Most teachers traditionally use imperative constructions in order to instruct students during the lessons. Phrases like "Answer the questions to the text", "Come out and write the words on the blackboard" should be substituted by "Please, will you answer the questions to the text", "Would you come out and write the words on the blackboard".

3. Avoiding personification and declarations. Instead of "I" (I think we can start; I want you to compare the words), it is preferable to use "we" or polite addressings (Let's write down the task. Please, study the rule).

Together with the verbal forms of communication, the non-verbal ones also play an important role reflecting 
the real attitude of a speaker. Communication reflects the emotions of those who communicate. Non-verbal communication like "language of emotions" is often even more expressive than the words. The special attention should be paid to the placement of desks in the study room. Face-to-face positioning together with friendliness adds comfort and warmth.

It is important to focus on the students' achievements rather than bad moments in the evaluation process (giving the marks). Students should not be compared: it is much more important to compare the "today's" results with the previous ones and focus on the progress.

4. Adherence to etiquette principles. Modern etiquette serves as means of communication, regulation of personal attitude and interconnection between people. The main principles of etiquette are humanism, cooperation, humanity, which are embodied in a number of moral requirements: politeness, tact, delicacy, modesty and punctuality.

Keeping the principles of politeness comprises the important linguistic and social component of the language behaviour of the Englishmen. It is important for a future doctor to acquire the nuances of using the phrases of apologising, thanking, sympathising. By training the intonation and pronunciation of the large variety of such phrases, it is also easy to train the voice so that the interlocutor (patient, colleague) feels the interest and sympathy.

No less important is the study material itself: patientdoctor dialogues, situational dialogues, patient examining, health care systems' descriptions and the like. They can be used at different stages of the lesson for training different skills of English reading, speaking, oral comprehension, and even writing.

Research results and recommendations. To test the created pedagogical technology in the experimental groups, the specially selected study material was used in the study process according to the defined principles. The study programme included target, methodological content and process components which contributed to qualitative and quantitative evaluation of the results.

The evaluation of the levels of humanistic value orientations' development was carried out at the beginning and at the end of the experiment. The humanistic value orientations were defined as positive-active attitude of a personality to itself and the world around, which is based on the principles of general human values' priority and corresponding view of life.

\section{ЛІТЕРАТУРА}

1. Дроздова О., Літвін О. Національний інтерес вищої освіти України в умовах Болонського процесу / О. Дроздова, О. Літвін // Збірник наукових праць Полтавського державного педагогічного університету ім. В. Г. Короленка. -2012. - №3. - С.38-457.

2. Сокурянська Л. Г. Ціннісна диференціація українського студенства: кластерний аналіз
The final evaluation showed that in the experimental group the high level of humanistic value orientations' development has increased to $31 \%$. The low level in the control group has increased to $25.6 \%$. It has resulted from the changes in students' level of humanistic value orientations. At the same time, in the experimental group, the percentage of the students with the low level of humanistic value orientations' development decreased from $22.5 \%$ to $15.3 \%$.

There is also the dynamics in both groups with the medium level: in the control group, the number of students with the medium level of humanistic values' development decreased from $50 \%$ to $45.8 \%$, while in the experimental group, this level increased from $50 \%$ to $54.7 \%$.

Before the experiment, the percentage of the students with the high and medium levels of humanistic values' development was $77.5 \%$ in both groups. The result of the experiment is $85.7 \%$, which proves the effectiveness of the created technology.

The generalising of the experimental work results proved that the study material used at the lessons of the English language at a medical university is an important means of the formation of humanistic value orientations. Therefore, the educators face the necessity of the material selection and study process humanisation.

Conclusions. The humanistic value orientations being a phenomenon of individual consciousness are the system of principles, motives, interests and needs. They are an important part of the motivational structure of a personality. Values and value orientations are humanistic if their content is filled with the norms of kindness, tolerance, justice and respect for others. These particular qualities should be the integral part of the future doctors' beliefs and behaviour. The educator should understand exactly what kind of qualities and value orientations will be formed with the help of the selected study material.

The high level of the humanistic values' development can be reached when the technology of their formation will be based on:

- evaluation and taking into account psychological characteristics of students;

- $\quad$ using educative potential of the study material;

- development of value consciousness on the bases of emotional, informative and volitional components of a future doctor's personality.

Only adherence to all above-mentioned principles will lead to the future doctors' humanistic consciousness formation, which is the leading quality of a medical professional.

Л. Г. Сокурянська // Методологія, теорія та практика соціологічного аналізу сучасного суспільства. Збірник наукових праць. - Харків : ВЦ ХНУ ім. В. Н. Каразіна. - 2003. - С.534-539.

3.Темех Н. Д. Українське телебачення і проблеми виховання молоді (за оцінками науковців та журналісті-практиків) / Н. Д. Темех // Доповіді та повідом- 
лення восьмої всеукраїнської конференції «Українська періодика: історія і сучасність». - Львів. - 2002. C.566-570.

4. Закон України «Про освіту»: прийнятий 4 червня 1991№ 1144-XII, в редакції від 9.08.2016.

5. A medical student elective promoting humanism, communication skills, complementary and alternative medicine and physician self-care / M. Dossett, V. Kuhatsu, V. Nunley, D. Mehta, R. Davis, R. Phillips, G. Weh // Explore (NY). - 2013. - Vol. 9. - Issue 5. - p. 292-298.

6. Lee W. N., Langiulli M., Mumtaz A. \& Peterson S. J. A comparison of humanistic qualities among medical students, residents, and faculty physicians in internal medicine / W. N. Lee, M. Langiulli, A. Mumtaz, S. J.

\section{REFERENCES}

1. Drozdova, O. \& Litvin, O. (2006). Natsionalnyi interes vyshchoi osvity Ukrainy v umovakh Bolonskoho protsesu [The national interest of the Ukrainian higher education in Bologna process conditions]. Zbirnyk naukovykh prats Poltavskoho derzhavnoho pedahohichnoho universytetu imeni $V$. G. Korolenka-Collection of scientific articles of Poltava V. G. Korolenko National Pedagogical University, 3, 38-45 [in Ukrainian].

2. Sokurianska, L. H. (2003). Tsinnisna dyferentsiastiia Ukrainskoho studenstva: klasternyi analiz [Value differentiation of Ukrainian students: cluster analysis]. Metodolohiia, teoriia ta praktyka sotsiolohichnoho analizu suchasnoho suspilstva. Knyha naukovykh prats Methodology, theory and practice of sociological analysis of the modern society. The book of scientific papers. (pp. 534-539) [in Ukrainian].

3. Temekh, N. D. (2002). Ukrainske telebachennia i problemy vykhovannia molodi (za otsinkamy naukovtsiv ta zhurnalistiv praktykiv) [Ukrainian television and the problems of youth upbringing (by the evaluation of scientists and practical journalists)]. Dopovidi ta povidomlennia vosmoi vseukrainskoi konferentsii "Ukrainska periodyka: isoriia i suchasnist" - Proceedings from 8th Ukrainian Conference "Ukrainian periodicals: history and modernity”. (pp. 566-570). Lviv [in Ukrainian].

4. Zakon Ukrainy "Pro Osvitu": pryiniatyi 4 cherv. $1991 v$ redaktsii vid 9.08.2016, № 1144-XII [The Law
Peterson // Heart Diseases. - 2003. - Vol. 5(6). - p. 380383.

7. Lewis D. Humanism and the art of medicine / D. Lewis // Momentum. -2012. - Volume 1(2).

8. Nelson K. Investigating future physician preparedness for providing humanistic care to dying patient / K. Nelson // Proceedings of the national conference on undergraduate research. - Cheney, WA: Eastern Washington University, 2015. - p. 465-472.

9. Rousseau Paul. Has medicine lost its compassion and humanism? / P. Rousseau // Journal of the American medical association. - 2007. - p. 1859-1860.

10. Sura N. A. Teacher's strategies in language classroom / N. Sura // Middle-East journal of scientific research. - 2012. - №12 (9). - p. 1224-1230.

"On Education" dated 4th June 1991 as amended 9.08.2016, No. 1144-XII]. (2016). [in Ukrainian].

5. Dossett, M., Kuhatsu, V., Nunley, V., Mehta, D., Davis, R., Phillips, R., \& Weh, G. (2013). A medical student elective promoting humanism, communication skills, complementary and alternative medicine and physician self-care. Explore (NY), 5, 292-298. (Vols. 9) [in English].

6. Lee, W. N., Langiulli, M., Mumtaz, A., \& Peterson, S. J. (2003). A comparison of humanistic qualities among medical students, residents, and faculty physicians in internal medicine. Heart Diseases. (Vols. 5(6)). (pp. 380-383) [in English].

7. Lewis, D. (2012). Humanism and the art of medicine. Momentum, 1(2) [in English].

8. Nelson, K. (2015). Investigating future physician preparedness for providing humanistic care to dying patient. Proceedings of the national conference on undergraduate research. (pp. 465-472). Cheney, WA: Eastern Washington University [in English].

9. Rousseau, Paul (2007). Has medicine lost its compassion and humanism? Journal of the American Medical Association. (pp. 1859-1860) [in English].

10. Sura, N. A. (2012). Teacher's strategies in language classroom. Middle-East journal of scientific research, 12 (9), 1224-1230 [in English].

\section{Ольга Аркадї̈вна Ціхоцька, кандидат педагогічних наук, доцент, Людмила Федорівна Лозинська, кандидат педагогічних наук, доцент, кафедра іноземних мов, Вінницький національний медичний університет імені М.І. Пирогова, вул. Пирогова, 56, м. Вінниця, Украӥна}

\section{ГУМАНІЗМ ТА ГУМАННІСТЬ ЯК ОСОБИСТІСНІ ЯКОСТІ МАЙБУТНЬОГО ЛІКАРЯ: СУЧАСНИЙ СТАН І ШЛЯХИ ФОРМУВАННЯ}

Статтю присвячено проблемі дослідження ціннісних орієнтацій майбутніх лікарів та їх формуванню в процесі вивчення іноземної мови. Українське суспільство зазнає змін, які впливають на внутрішній світ молодих людей. Сучасна освіта повинна не тільки надавати інформацію, але й сприяти формуванню найкращих якостей у майбутніх фахівців. Гуманізм повинен стати невід’ємною рисою особистості майбутнього лікаря. Поняття 
гуманізму досліджувалось різними галузями наук. Педагогіка розглядає гуманізм як всебічне та гармонічне виховання молодих людей та роз'яснює сутність виховання в сучасному суспільстві. Автори зробили спробу проаналізувати поточний рівень формування гуманістичних ціннісних орієнтацій(ГЦО) у майбутніх лікарів, виявити специфіку гуманістичного виховання під час викладання предмету "Англійська мова», розробити педагогічні умови та методику формування гуманістичних ціннісних орієнтацій у майбутніх лікарів. Констатуючий експеримент надав можливості визначити початкові рівні сформованості гуманістичних ціннісних орієнтацій майбутніх лікарів (високий - 27,5\%, середній - 50\% та низький - 22,5\%). На підставі отриманих результатів автори розробили та експериментально перевірили технологію виховання ГЦО у майбутніх лікарів. Оскільки цінності є важливою частиною мотиваційної структури особистості, важливо щоб вони були гуманістичними, тобто наповнені нормами доброти, толерантності, терпимості. Саме вихованню таких якостей сприяє розроблена педагогічна технологія, що базується на оцінці та урахуванні психологічних особливостей сучасного студентства, використанні виховних можливостей навчального матеріалу 3 англійської мови та розвитку ціннісної свідомості шляхом включення в педагогічний процес емоційної, вольової та пізнавальної сфер особистості майбутнього лікаря. Результатом запровадження авторської технології було збільшення високого та середнього рівня сформованості ГЦО сукупно з 77,5\% до 85,7\% що підтверджує іï результативність.

Ключові слова: ціннісні орієнтації, гуманізація, англійська мова, гуманістичні цінності, виховання, виховні можливості навчального матеріалу.

Ольга Аркадиевна Цихоцкая, кандидат педагогических наук, доиент, Людмила Федоровна Лозинская, кандидат педагогических наук, доцент, кафедра иностранных языков, Винницкий национальный медицинский университет имени Н.И. Пирогова, ул. Пирогова, 56, г. Винница, Украина

\section{ГУМАНИЗМ И ГУМАННОСТЬ КАК ЛИЧНОСТНЫЕ КАЧЕСТВА БУДУЩЕГО ВРАЧА: СОВРЕМЕННОЕ СОСТОЯНИЕ И ПУТИ ФОРМИРОВАНИЯ}

Статья посвящена проблеме исследования ценностных ориентаций будущих врачей и их формированию в процессе изучения иностранного языка. Украинское общество претерпевает изменения, которые влияют на внутренний мир молодых людей. Современное образование должно не только предоставлять информацию, но и способствовать формированию лучших качеств у будущих специалистов. Авторы сделали попытались проанализировать текущий уровень сформированности гуманистических ценностных ориентаций (ГЦО) у будущих врачей, выявить специфику гуманистического воспитания в процессе преподавания предмета «Английский язык», разработать педагогические условия и методику формирования гуманистических ценностных ориентаций у будущих врачей. Констатирующий эксперимент дал возможность выявить начальные уровни сформированности гуманистических ценностных ориентаций будущих докторов (высокий $-27,5 \%$, средний - 50\% и низкий $-22,5 \%$ ). На основе полученных результатов авторы разработали и экспериментально апробировали технологию формирования ГЦО у будущих докторов. Поскольку ценности являются важной составляющей мотивационной структуры личности, важно чтобы они были гуманистичными, наполненными идеалами добра, толерантности, терпимости. Именно воспитанию таких качеств способствует разработанная технология, которая базируется на выявлении и учете индивидуальных психологических особенностей студенчества, использовании воспитательных возможностей учебного материала и развитии ценностного сознания путем включения в педагогический процесс эмоциональной, волевой и познавательной сфер личности будущего доктора. В результате применения авторской технологии высокий и средний уровень сформированности ГЦО увеличился с 77,5 \% до 85,7 \% совокупно, что подтверждает ее эффективность.

Ключевые слова: ценностные ориентации, гуманизация, английский язык, гуманистические ценности, воспитание, воспитательные возможности учебного материала.

Рецензент: д. пед. н., проф. І. В. Бужина

Подано до редакиії 25.10.2016 